\title{
Development of Nitrogen-Containing Fertilizer Based on Pine Bark and Study of its Effectiveness in Wheat Growing in the Agricultural Zone of the Krasnoyarsk Territory
}

\author{
Mikhail Yu. Belash*a, Evgenia V. Veprikova ${ }^{a}$, \\ Anatoly A. Soboleva, Vasily N. Romanovb, \\ Natalia S. Kozulinab ${ }^{b}$ Tatiana A. Snitkova ${ }^{b}$, \\ Albina V. Vasilenkob ${ }^{b}$, Mikhail A. Mikhailets ${ }^{b}$, \\ Alexey G. Lipshin ${ }^{\mathrm{b}}$ and Oxana P. Taran ${ }^{\mathrm{a}, \mathrm{c}}$ \\ ${ }^{a}$ Institute of Chemistry and Chemical Technology SB RAS \\ FRC "Krasnoyarsk Science Center SB RAS" \\ Krasnoyarsk, Russian Federation \\ ${ }^{b}$ Krasnoyarsk Research Institute of Agriculture $S B R A S$ \\ FRC "Krasnoyarsk Science Center SB RAS” \\ Krasnoyarsk, Russian Federation \\ 'Siberian Federal University \\ Krasnoyarsk, Russian Federation
}

Abstract. A method for production a new fertilizer was proposed. This method is based on the impregnation of a substrate from pine bark with a water solution of ammonium nitrate, and containing 20.0 wt. \% nitrogen. The physicochemical properties of a pine bark substrate and prepared fertilizers were studied. A field experiment was conducted on growing wheat of the variety "Krasnoyarskaya 12". The yield of wheat when fertilized with pine bark was applied to the soil increased by 2.9 centners/ ha compared to blank experiment without fertilizer. The use of this fertilizer results in an increase in the quality (higher nutritional value) of the grains in comparison blank experiments with ammonium nitrate and without fertilizer.

Keywords: pine bark, ammonium nitrate, wheat, field experiment, yield, seed nature.

(C) Siberian Federal University. All rights reserved

This work is licensed under a Creative Commons Attribution-NonCommercial 4.0 International License (CC BY-NC 4.0).

* Corresponding author E-mail address: belash_mikhail@mail.ru 
Citation: Belash M.Yu., Veprikova E.V., Sobolev A.A., Romanov V.N., Kozulina N.S., Snitkova T.A., Vasilenko A.V., Mikhailets M.A., Lipshin A.G., Taran O.P. Development of nitrogen-containing fertilizer based on pine bark and study of its effectiveness in wheat growing in the agricultural zone of the krasnoyarsk territory, J. Sib. Fed. Univ. Chem., 2020, 13(4), 578-592. DOI: 10.17516/1998-2836-0207

\title{
Разработка азотсодержащего удобрения
}

на основе коры сосны и изучение

его эффективности при выращивании пшеницы

в земледельческой зоне Красноярского края

\author{
М.Ю. Белаш ${ }^{a}$, Е.В. Веприкова ${ }^{a}$, \\ А.А. Соболев ${ }^{\text {a }}$, В.Н. Романов ${ }^{\sigma}$, \\ Н.С. Козулина ${ }^{\tilde{\sigma}}$, Т.А. Сныткова ${ }^{\boldsymbol{\sigma}}$, А.В. Василенко \\ М.А. Михайлец ${ }^{\sigma}$, А.Г. Липшин ${ }^{\sigma}$, О.П. Таран ${ }^{\text {a,в }}$ \\ ${ }^{a}$ Институт химии и химической технологии \\ ФИЦ «Красноярский научный иентр СО РАН» \\ Российская Федерация, Красноярск \\ ${ }^{\sigma}$ Красноярский научно-исследовательский институт \\ сельского хозяйства \\ ФИЦ «Красноярский научный иентр СО РАН» \\ Российская Федераиия, Красноярск \\ ${ }^{8}$ Сибирский федеральный университет \\ Российская Федераиия, Красноярск
}

Аннотация. Предложен основанный на пропитке подложки из коры сосны водным раствором аммиачной селитры способ получения нового удобрения, содержащего 20,0 мас. \% азота. Изучены физико-химические свойства подложки из коры сосны и удобрения на ее основе. Результаты полевого опыта по выращиванию пшеницы сорта «Красноярская 12» показали, что урожайность пшеницы при внесении в почву удобрения на основе коры сосны увеличилась на 2,9 ц/га по сравнению с неудобренным фоном. Применение данного удобрения приводит к увеличению натуры зерна в сравнении с аммиачной селитрой и неудобренным фоном, что характеризует более высокую его пищевую ценность.

Ключевые слова: кора сосны, аммиачная селитра, пшеница, полевой опыт, урожайность, натура зерна.

Цитирование: Белаш, М.Ю. Разработка азотсодержащего удобрения на основе коры сосны и изучение его эффективности при выращивании пшеницы в земледельческой зоне Красноярского края / М.Ю. Белаш, Е.В. Веприкова, А.А. Соболев, В.Н. Романов, Н.С. Козулина, Т.А. Сныткова, А.В. Василенко, М.А. Михайлец, А.Г. Липшин, О.П. Таран // Журн. Сиб. федер. ун-та. Химия, 2020. 13(4). С. 578-592. DOI: 10.17516/1998-2836-0207 


\section{Введение}

Кора различных пород деревьев является многотоннажным отходом современных деревообрабатывающих, целлюлозно-бумажных производств [1, 2], поскольку на ее долю приходится 13-21 мас. \% от древесной биомассы [3]. В настоящее время более половины отходов коры утилизируется сжиганием или складируется, образуя пожароопасные отвалы. Частично такие отходы используются как дешевый источник энергии на предприятиях ЦБП. Однако древесная кора считается низкокачественным топливом для прямого производства энергии, а также переработки в пеллеты и брикеты из-за высокого содержания золы, низкой точки спекания и низкой теплотворной способностью по сравнению с древесиной. Следовательно, разработка методов квалифицированной переработки древесной коры имеет важное значение с точки зрения рационального природопользования.

Традиционным направлением утилизации отходов древесной коры является получение органоминеральных удобрений для сельского хозяйства. Большой интерес представляет получение удобрений, способных к медленному выделению питательных элементов в почву и обладающих эффектом пролонгированного действия $[4,5]$. Медленное выделение питательных элементов в почву повышает их биодоступность для растений, поэтому удобрения пролонгированного действия более эффективны по сравнению с традиционными водорастворимыми удобрениями $[6,7]$. Получение азотсодержащих удобрений подобного действия представляет практический и научный интерес, так как азот необходим для достижения высокой урожайности и качества сельскохозяйственных культур. Интенсивное применение традиционных азотсодержащих минеральных удобрений может привести к неблагоприятным экологическим рискам - к повышению миграционной активности растворимых форм азота, к увеличению эвтрофикации природных вод и эмиссии закиси азота [8]. Известно, что применение удобрений пролонгированного действия позволяет существенно снизить негативную нагрузку на окружающую среду при большем достигаемом экономическом эффекте [9].

В литературе имеются сведения об удобрениях с замедленным выделением азота, полученных пропиткой лигноцеллюлозных пористых носителей (например, древесных опилок, коры осины и пихты) водными растворами соответствующих соединений (нитрата аммония, мочевины и нитрата калия) [10-12]. Следует отметить, что ростостимулирующее действие таких удобрений изучали в лабораторных опытах по проращиванию семян разных культур. Поэтому проведение испытания вновь разработанных удобрений в полевых условиях крайне важно для оценки их влияния на урожайность сельскохозяйственных культур.

Отходы коры сосны по своему масштабу и распространенности на территории России наиболее доступное сырье для получения новых видов удобрений. Поскольку древесная кора разной природы различается по физико-химическим свойствам и капиллярно-пористой структуре, изучение возможности создания на их основе новых азотсодержащих удобрений является актуальной задачей.

Цель настоящей работы состояла в разработке способа получения удобрения на основе коры сосны, содержащего аммиачную селитру, и в изучении его влияния на продуктивность яровой пшеницы сорта «Красноярская 12». 


\section{Экспериментальная часть}

Получение удобрения и исследование его физико-химических свойств

Сырьем для получения удобрения служила воздушно-сухая кора сосны (Pinus Sylvestris L.). Кору сосны измельчали на роторной ножевой мельнице марки РМ-120 с диаметром сита 3 мм. Далее производили фракционирование на виброгрохоте марки ГР-30 и выделяли фракцию коры размером 1-3 мм.

Процесс получения удобрения включал две основные стадии: 1) приготовление пористой подложки из коры сосны; 2) нанесение на подложку аммиачной селитры. Для получения подложки кору сосны обрабатывали 1,0\%-ным водным раствором $\mathrm{NaOH}$ при следующих условиях: температура $93 \pm 3{ }^{\circ} \mathrm{C}$; продолжительность 1 ч; значение гидромодуля равно 10; перемешивание. Промывку подложки водой и нейтрализацию остатков щелочи раствором 0,1 $\mathrm{N} \mathrm{HNO}_{3}$ (значения гидромодулей равны 9 и 7 соответственно) проводили так же, как и в работе [13]. Подложку сушили до воздушно-сухого состояния при $50 \pm 5^{\circ} \mathrm{C}$.

Нанесение аммиачной селитры (марка «ч») осуществляли пропиткой подложки ее водным

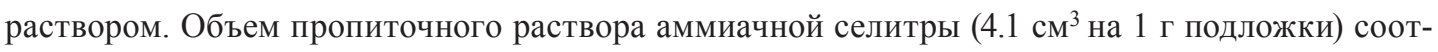
ветствовал влагоемкости подложки, которую определяли по ГОСТ 24160-80. На 1 кг подложки наносили 800,58 г аммиачной селитры. Это количество рассчитано так, чтобы удобрение содержало 20,0 мас. \% азота. Пропиточный раствор добавляли к подложке порциями при непрерывном перемешивании. Пропитанную подложку уплотняли и выдерживали в закрытой таре в течение 15-20 ч при комнатной температуре. Затем сушили до воздушно-сухого состояния при $100-105^{\circ} \mathrm{C}$.

Приготовлено 50 кг азотсодержащего удобрения следующего состава (мас. \%): 42,83 подложка из коры сосны, 57,17 аммиачная селитра (20,0 мас. \% азота). Насыпная плотность удобрения составляет 0,17 г/см³.

Электронно-микроскопические исследования (РЭМ) удобрения проводили на электронном растровом микроскопе ТМ-1000 (НITACHI, Япония).

Регистрация ИК-спектров подложки, удобрения на ее основе и аммиачной селитры выполнена на ИК-Фурье спектрометре IR Tracer-100 (Shimadzu, Япония) в области волновых чисел 4000-400 см ${ }^{-1}$. Образцы готовили в виде таблеток в матрице бромистого калия. Масса подложки и удобрения на ее основе составляла 3 мг на 1000 мг бромида калия, а аммиачной селитры 2 мг при прочих равных условиях. Полученная спектральная информация была обработана с помощью пакета программ LabSolutions IR.

Термические свойства подложки и удобрения на ее основе были исследованы методами ТГ, ДТГ и ДСК на термоанализаторе STA 449F1 фирмы NETZSCH (Германия) в температурном интервале от 28 до $900{ }^{\circ} \mathrm{C}$ в атмосфере аргона. Скорость нагрева образцов составляла $10{ }^{\circ} \mathrm{C} /$ мин.

Содержание в исходной коре и подложке водорастворимых веществ (при комнатной температуре $22 \pm 1^{\circ} \mathrm{C}$ ) и лигнина (в модификации Комарова) определяли согласно принятым в химии древесины методикам [14].

\section{Проведение полевых испытаний}

Эффективность действия азотсодержащего удобрения на основе коры сосны изучали по влиянию на продуктивность яровой пшеницы сорта «Красноярская 12» в сравнении с амми-

$$
-581-
$$


ачной селитрой и неудобренным фоном (контроль) в условиях стационарного полевого опыта. Полевой опыт проводился на участке, расположенном в зоне Красноярской лесостепи, с географическими координатами: широта $56^{\circ} 03^{\prime}$ СШ и $92^{\circ} 42^{\prime}$ ВД. Период проведения опыта - с 8 мая по 14 сентября 2020 г. Почва на участке представляет собой чернозем обыкновенный, маломощный, среднесуглинистый (агрочернозем криогенно-мицеллярный) со следующими характеристиками: содержание гумуса в слое 0-20 см 8,36-8,72 \%; слабощелочная реакция среды ( $\left.\mathrm{pH}_{2} \mathrm{O} 7,1-7,8\right)$; сумма обменных оснований (40,0-45,5 м-экв/100 г); содержание $\mathrm{P}_{2} \mathrm{O}_{5}$ 50,4-67,4 мг/кг и $\mathrm{K}_{2} \mathrm{O} 214,0-269,0$ мг/кг (по Мачигину) $[15,16]$. Предельная полевая влагоемкость метрового слоя почвы составляет 323 мм.

Выбор участка, схема и закладка опыта, фенологические наблюдения проведены по соответствующим методикам [17-20] 20 апреля 2020 г. Схема полевого опыта отражена в табл. 1.

Площадь участка полевого опыта составляет 264,6 м² (12,6 х 21 м), учетная площадь (площадь контрольного участка) - 29,4 м² (4,2 х 7 м). Размещение вариантов опыта на площади очередное, повторность опыта трехкратная.

Опытный участок вспахан 8 мая на глубину 20-22 см. Дискование поверхности проведено 12 мая. Удобрения (аммиачную селитру и удобрения на основе коры сосны) вносили на глубину 7 см. Посев семян пшеницы производили на глубину 5 см 20 мая 2020 г. Норма внесения азотсодержащего удобрения на основе коры сосны составляла 170 кг/га, аммиачной селитры 100 кг/га. Норма высева семян пшеницы 3,5 млн шт. на 1 га (150,5 кг/га семян пшеницы). Уборка урожая проведена 14 сентября.

Перед посевом в лабораторных условиях определено качество посевного материала: чистота семян пшеницы (99 \%, по ГОСТ 12037-81), всхожесть и энергия прорастания (82 \% и 55 \% соответственно, по ГОСТ 12038-84), натура зерна (780 г/л, по ГОСТ 0840-2017). На основании полученных данных рассчитывали норму высева семян на 1 га.

Характеристика посевов пшеницы в полевом опыте проводилась по общепринятым методикам [21]. Натуру (вес 1 л зерна в граммах, г/л) полученного зерна определяли по ГОСТ 10840-2017.

Отбор образцов почвы для определения содержания влаги [22] проведен 21 мая на глубину 0,5 м через 10 см. Одновременно были отобраны образцы почвы для определения содержания в ней элементов питания. Отбор проб почвы и ее анализ осуществляли по методикам ГОСТ 5898-2019 и [23]. Содержание азота, фосфора и калия в зерне контролировали согласно [24].

Достоверность влияния внесения удобрений на урожайность пшеницы $\left(\mathrm{HCP}_{05}\right)$ оценивали с помощью дисперсионного анализа [25].

Таблица 1. Схема полевого опыта

Table 1. The field experiment scheme

\begin{tabular}{|c|c|}
\hline № & Вариант опыта \\
\hline 1 & Без удобрений (контроль) \\
\hline 2 & Аммиачная селитра $(100$ кг/га) \\
\hline 3 & Удобрение на основе коры сосны $(170$ кг/га) \\
\hline
\end{tabular}


Таблица 2. Погодные условия вегетационного периода полевого опыта 2020 г.

Table 2. Weather conditions in vegetative season of the field experiment 2020 year

\begin{tabular}{|c|c|c|c|c|}
\hline \multirow{2}{*}{ Дата } & \multicolumn{3}{|c|}{ Температура воздуха, ${ }^{\circ} \mathrm{C}$} & \multirow{2}{*}{ Осадки, } \\
\cline { 2 - 5 } & Минимум & Средняя & Максимум & 53 \\
\hline Май, 3-я дек. & & 16,2 & 15,5 & 50 \\
\hline Июнь, 1-я дек. & 7,7 & 11,7 & 22,7 & 26,7 \\
\hline 2-я дек. & 12,2 & 17,0 & 24,5 & 17,3 \\
\hline 3-я дек. & 13,7 & 18,5 & 20,9 & 94 \\
\hline За июнь & 11,2 & 15,7 & 24,5 & 77 \\
\hline Июль, 1-я дек. & 16,5 & 19,4 & 23,8 & 27,3 \\
\hline 2-я дек. & 12,8 & 18,0 & 22,9 & 111,3 \\
\hline 3-я дек. & 13,1 & 17,4 & 23,7 & 39,6 \\
\hline За июль & 14.1 & 18,2 & 23,9 & 10,8 \\
\hline Август, 1-я дек. & 13,5 & 18,1 & 26,0 & 26,5 \\
\hline 2-я дек. & 13,4 & 19,0 & 23,6 & 76,9 \\
\hline 3-я дек. & 12,3 & 17,3 & 24,5 & 34,1 \\
\hline За август & 13,1 & 18,1 & 19,2 & \\
\hline Сентябрь, 1-я дек. & 8,9 & 13,3 & & \\
\hline
\end{tabular}

Данные о погодных условиях в полевом опыте по сведениям интернет-портала [26] приведены в табл. 2. Всего за вегетацию выпало 369 мм осадков (больше среднегодичного количества 340 мм) при средней температуре $16,3{ }^{\circ} \mathrm{C}$.

\section{Результаты и обсуждение}

\section{Свойства азотсодержащего удобрения}

на основе пористой подложки из коры сосны

В разработанном в ИХХТ СО РАН азотсодержащем удобрении пористая подложка из коры сосны является носителем аммиачной селитры и органическим компонентом удобрения, за счет биоразложения которого почва обогащается дополнительным количеством гумуса. Длительность процесса биоразложения позволяет считать подложку из коры сосны органическим удобрением замедленного действия. За счет набухания подложки внесение удобрения способствует удержанию влаги в почве, а благодаря размерам частиц удобрения (1-3 мм) - разрыхляет ее.

Кора сосны содержит фенольные соединения разной природы, в том числе и кислоты, которые способны отрицательно влиять на прорастание семян и развитие растений $[4,27]$. За счет обработки коры сосны 1,0\%-ным водным раствором $\mathrm{NaOH}$ было удалено 34,7 мас. \% различных органических веществ. Удаление щелочерастворимых веществ из пор и капилляров коры приводит к увеличению проницаемости подложки для воды, о чем свидетельствует увеличение ее влагоемкости по сравнению с исходной корой в 1,6 раза (табл. 3).

Повышение показателя влагоемкости не только позволяет увеличить количество наносимой на подложку аммиачной селитры (за счет увеличения объема пропиточного раствора), но и способствует более равномерному ее распределению в матрице подложки. Кроме того, высокая

$$
-583-
$$


Таблица 3. Свойства коры сосны и пористой подложки на ее основе

Table 3. Properties of a pine bark and a prepared porous support

\begin{tabular}{|c|c|c|c|}
\hline Образец & ВЛ, $\mathrm{cm}^{3} / \Gamma$ & ВРВ, \%* & Лигнин, мас. \%* \\
\hline Кора сосны & 2,5 & 10,3 & 37,7 \\
\hline Пористая подложка & 4,1 & 5,8 & 44,1 \\
\hline
\end{tabular}

Примечание. ВЛ - влагоемкость; ВРВ - содержание веществ, растворимых в воде; * \% от массы а.с. образца.

влагоемкость подложки определяет влагоудерживающую способность удобрения на ее основе. Подложка, абсорбируя излишек влаги и отдавая ее по мере подсыхания почвы, будет положительно влиять на водный баланс.

Водно-щелочной гидролиз позволил в 1,8 раза уменьшить содержание в подложке водорастворимых веществ по сравнению с исходной корой (табл. 3). Это способствует повышению безопасности удобрения на ее основе, поскольку водорастворимые полифенольные соединения при их высоком содержании оказывают на растения ингибирующее действие [4].

Подложка из коры сосны, входящая в состав удобрения, содержит 44.1 \% лигнина (табл. 3), последний является источником образования гумусовых веществ в результате биоразложения удобрения в почве.

Нанесение аммиачной селитры проводили пропиткой подложки водным раствором, $\mathrm{NH}_{4} \mathrm{NO}_{3}$ с учетом влагоемкости подложки (объем раствора для пропитки сопоставим с объемом пор пористой подложки из коры сосны). Выбранный метод «пропитки по влагоемкости» широко применяется при получении нанесенных катализаторов и позволяет нанести на подложку точно заданное количество аммиачной селитры [28].

Исследование морфологии азотсодержащего удобрения на основе подложки из коры сосны выявило высокую равномерность распределения частиц аммиачной селитры на его поверхности. Частицы $\mathrm{NH}_{4} \mathrm{NO}_{3}$ локализованы по краям крупных пор подложки и заполняют более мелкие поры (например, поры шириной от 3 до 12 мкм) (рис. 1a, б).

Наблюдаемый характер распределения $\mathrm{NH}_{4} \mathrm{NO}_{3}$ на поверхности подложки будет влиять и на удаление азота при взаимодействии удобрения с водой. Локализация частиц аммиачной селитры в мелких порах подложки, очевидно, способна затруднять переход азота в почвенный раствор вследствие внутридиффузионных процессов. За счет этого может происходить медленное вымывание азота водой в течение длительного времени, что определяет эффект пролонгированного действия удобрения. Удаление водой аммиачной селитры, находящейся по краям крупных пор, способно достаточно быстро обеспечить повышенное содержание азота в почвенном растворе, что необходимо для устранения дефицита этого элемента питания.

Следует отметить, что содержание азота в удобрении, равное 20 мас. \%, является максимальным и ограничено особенностью капиллярно-пористой структуры подложки из коры сосны. В предварительных экспериментах было установлено, что при повышении содержания азота до 22-25 \% визуально наблюдается побеление частиц удобрения за счет выноса аммиачной селитры фронтом испарения на внешнюю поверхность подложки. Очевидно, что в этом случае устойчивость удобрения к вымыванию азота водой будет снижаться. 

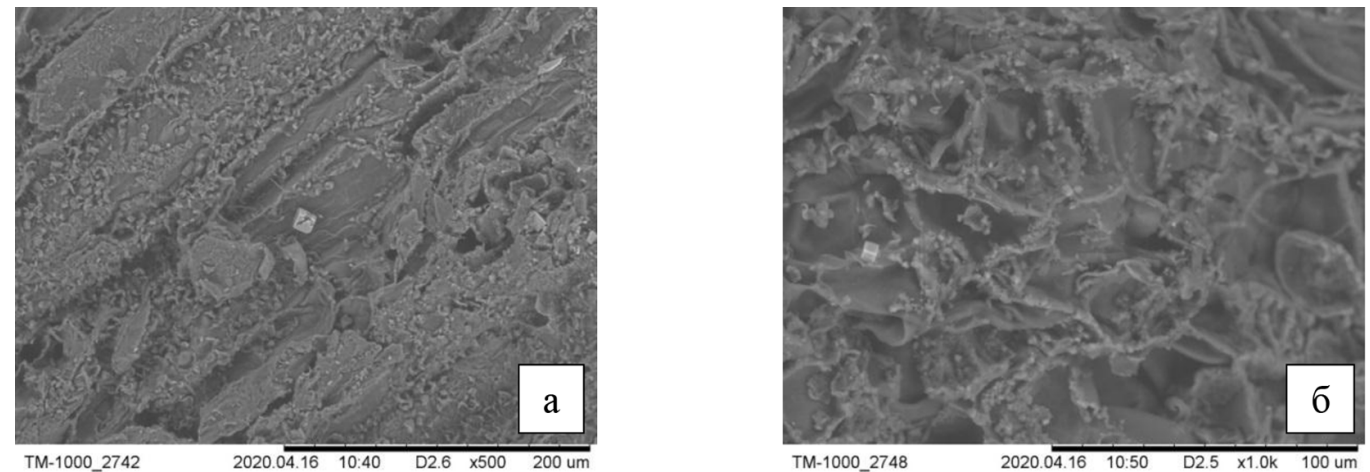

Рис. 1. РЭМ изображения удобрения на основе подложки из коры сосны: $a$, $\sigma$ - увеличение в 500 и 1000 ра3

Fig. 1. SEM images of the fertilizer prepared based on support from pine bark: $a$, $\sigma$ - magnification in 500 and 1000 times

Известно, что характер распределения вещества, нанесенного методом пропитки на пористую подложку, зависит от температуры сушки [28]. При получении азотсодержащего удобрения температура сушки составляла $100-105{ }^{\circ} \mathrm{C}$. Применение более высокой температуры нецелесообразно, поскольку выше $110{ }^{\circ} \mathrm{C}$ аммиачная селитра диссоциирует с образованием аммиака и азотной кислоты [29].

По данным термического анализа, диссоциации аммиачной селитры в составе удобрения соответствует эндотермический пик на кривой ДСК при температуре $123,3{ }^{\circ} \mathrm{C}$. Однако частичная диссоциация наблюдается уже при $113,3{ }^{\circ} \mathrm{C}$ (рис. $2 a$ ).

На кривой ДТГ удобрения, содержащего аммиачную селитру, идентифицированы два пика максимума потери массы при 181,3 и $213,7^{\circ} \mathrm{C}$ (рис. $2 a$ ), которые вызваны разложением аммиачной селитры до закиси азота и по другим известным механизмам с образованием NO, $\mathrm{N}_{2}, \mathrm{~N}_{2} \mathrm{O}_{3}$ и других побочных продуктов распада [29]. Процессам разложения $\mathrm{NH}_{4} \mathrm{NO}_{3}$ по разным механизмам соответствуют экзотермические пики на кривой ДСК при 182,1, 207,2 и 215,7 ${ }^{\circ} \mathrm{C}$.

Терморазложение аммиачной селитры протекает в пористой матрице подложки, что может затруднять отвод газообразных продуктов из ее объема. Взаимодействие органических компонентов подложки из коры сосны с продуктами распада селитры может приводить к смещению температуры разложения лигнина и целлюлозы в низкотемпературную область до $213,7^{\circ} \mathrm{C}$. О такой возможности свидетельствует отсутствие на кривой ДТГ удобрения максимумов потери массы при более высоких температурах. Для сравнения, на кривой ДТГ исходной подложки из коры сосны присутствует пик при $354,5^{\circ} \mathrm{C}$, обусловленный разложением лигнина и целлюлозы (рис. 2a, б).

Термостабильность аммиачной селитры в процессе сушки удобрения при $105{ }^{\circ} \mathrm{C}$ подтверждают результаты сравнения ИК-спектров полученного удобрения и $\mathrm{NH}_{4} \mathrm{NO}_{3}$ (рис. 3).

В удобрении идентифицированы полосы поглощения (п.п.) колебания структурных групп аммиачной селитры, например п.п. при 3037, 1389, 1044, 829 и 717 см$^{-1}$ [18]. Также отмечено отсутствие сдвига п.п. $\mathrm{NH}_{4} \mathrm{NO}_{3}$, входящей в состав удобрения, по сравнению с индивидуальным веществом (рис. 2, кривые 2 и 3). Данный факт свидетельствует об отсутствии терморазложения аммиачной селитры при выбранной температуре сушки удобрения. Сравнение 

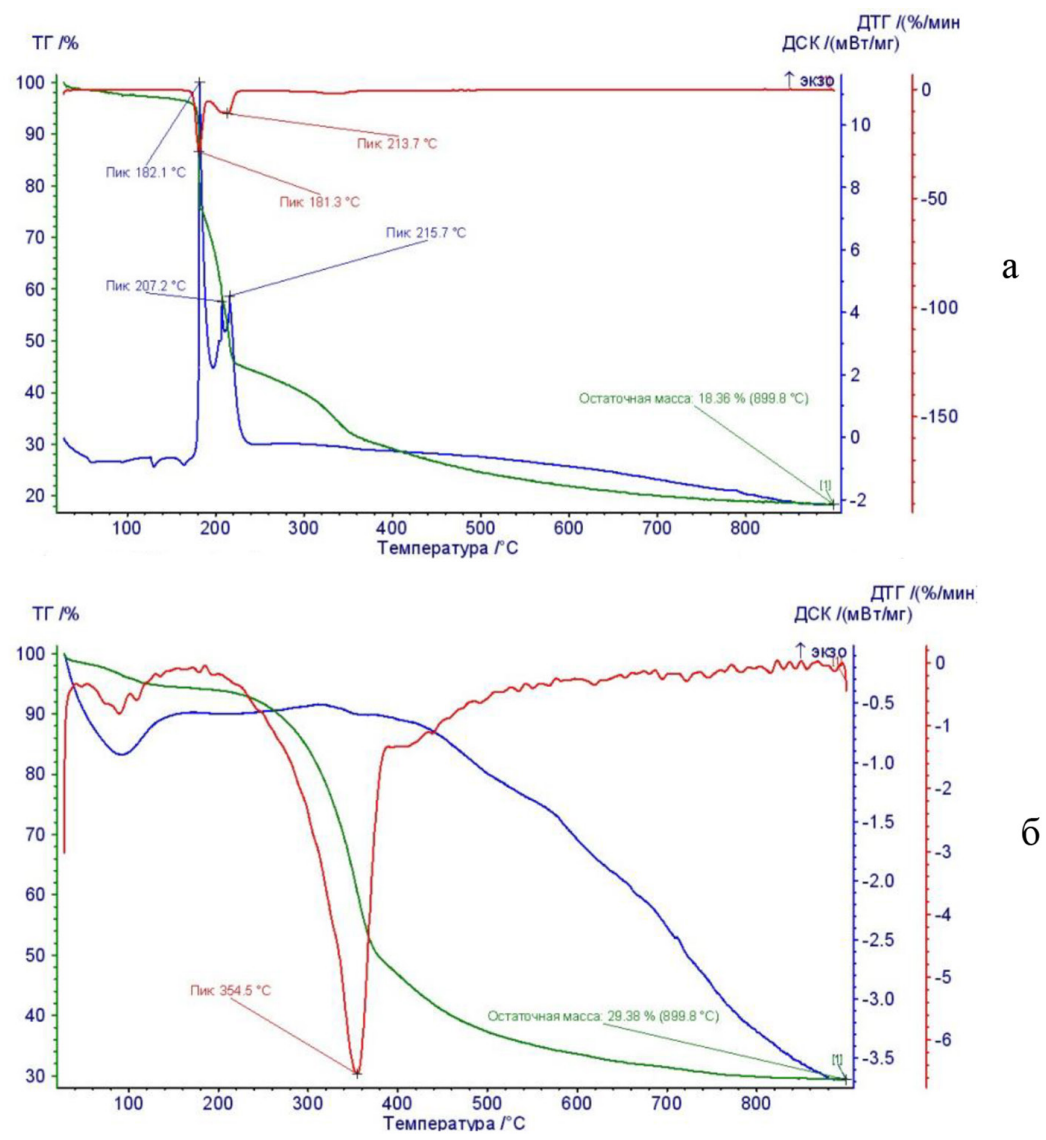

Рис. 2. Результаты термического анализа азотсодержащего удобрения на основе подложки из коры сосны (a) и исходной подложки (б)

Fig. 2. Results of thermal analysis of nitrogen containing fertilizer prepared based on support from pine bark (a) and initial support (б)

ИК-спектров подложки из коры сосны до и после нанесения аммиачной селитры показало отсутствие сдвига ее характеристических п.п. (рис. 2, кривые 1 и 2). Это, с учетом неизменности п.п. $\mathrm{NH}_{4} \mathrm{NO}_{3}$, свидетельствует об отсутствии взаимодействия подложки с нанесенным веществом [30]. Инертность подложки из коры сосны позволяет сохранить форму нахождения азота и его биоактивность, присущие аммиачной селитре.

\section{Результаты полевого опыта}

Формирование основных элементов структуры урожая пшеницы существенно зависит от влагообеспеченности в течение вегетационного периода. Расчетным путем установлено, что устойчивое увядание растений в опыте наступает при влажности метрового слоя почвы, равной $11,7 \%$. Созданию хороших условий накопления влаги способствует и структура пахотного слоя. В полевом опыте перед посевом объемная масса слоя почвы 0-10 см составляла 0,83-

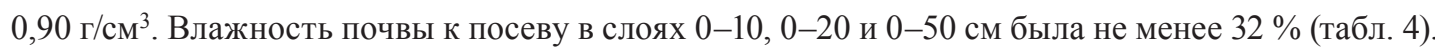

Наблюдаемый уровень влажности почвы способствовал быстрому, в течение недели, появлению всходов. Прежде всего всходы отмечены на варианте с применением аммиачной се- 


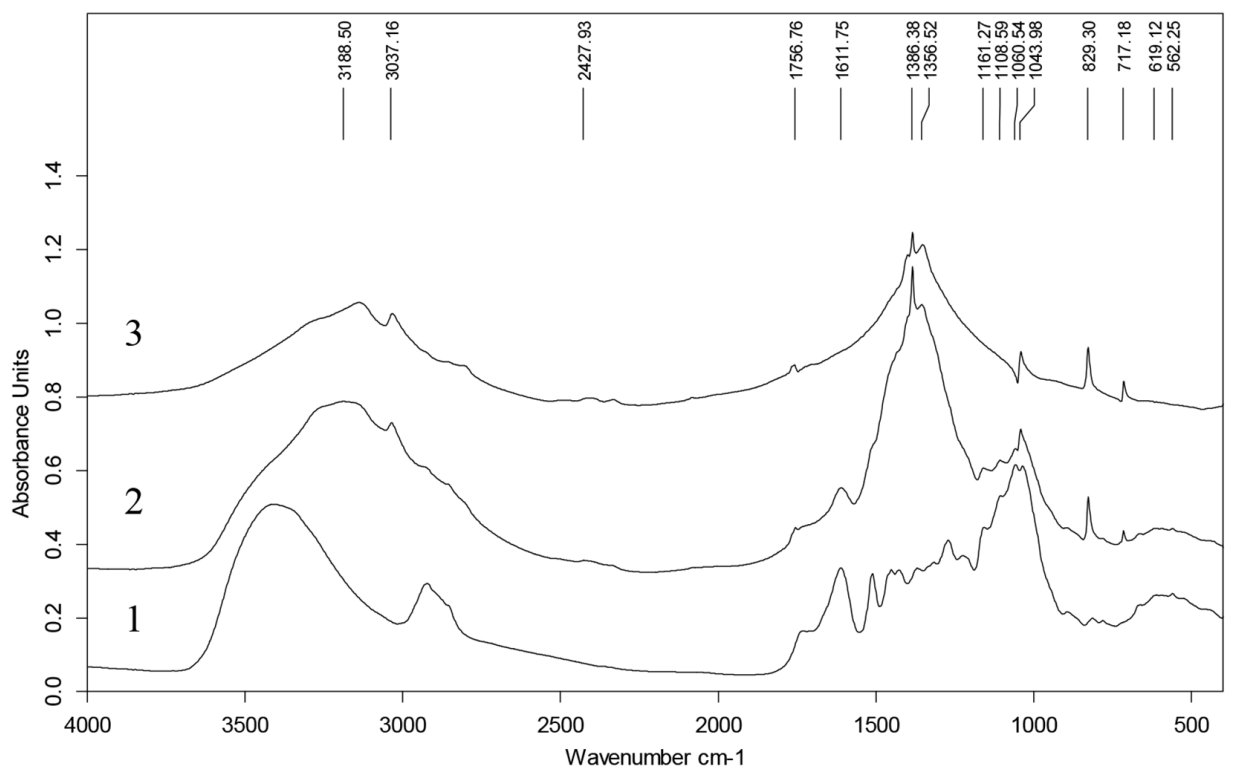

Рис. 3. ИК-спектры подложки из коры сосны (1), азотсодержащего удобрения на ее основе (2) и аммиачной селитры (3)

Fig. 3. IR spectrum of support from pine barks (1), nitrogen containing fertilizer on this support (2) and ammonium nitrate (3)

Таблица 4. Влажность почвы на разных стадиях полевого опыта

Table 4. Soil humidity on the different stages of the field experiment

\begin{tabular}{|c|c|c|}
\hline \multirow{2}{*}{ Горизонт почвы, см } & \multicolumn{2}{|c|}{ Влажность почвы, \% } \\
\cline { 2 - 3 } & Посев - всходы & Уборка \\
\hline $0-10$ & 33,4 & 27,0 \\
\hline $10-20$ & 30,9 & 18,0 \\
\hline $0-20$ & 32,1 & 22,5 \\
\hline $20-30$ & 31,4 & 13,0 \\
\hline $30-40$ & 31,6 & 14,0 \\
\hline $40-50$ & 32,5 & 13,0 \\
\hline $0-50$ & 32,0 & 17,0 \\
\hline
\end{tabular}

литры, через сутки - на варианте с применением удобрения на основе коры сосны и в контроле (без удобрений).

Данные табл. 4 показывают, что высокий уровень влагообеспеченности сохраняется в различных горизонтах почвы (особенно в слоях 0-10 и 0-20 см) в течение всего вегетационного периода. Очевидно, такие условия влажности в сочетании с температурами вегетационного периода (табл. 2) оказывают положительное влияние на рост и развитие пшеницы.

В полевом опыте было определено содержание основных элементов питания в почве на разных стадиях вегетации пшеницы при использовании удобрений в сравнении с неудобренным фоном. Результаты представлены в табл. 5. 
Таблица 5. Содержание элементов питания в почве

Table 5. The nutrition elements content in soil

\begin{tabular}{|c|c|c|c|c|c|}
\hline \multirow{2}{*}{ Вариант опыта } & \multicolumn{3}{|c|}{ Нитратный азот, мг/кг } & $\begin{array}{c}\text { Подвижный } \\
\text { фосфор, мг/кг }\end{array}$ & $\begin{array}{c}\text { Обменный калий, мг/кг } \\
\text { Кост }\end{array}$ \\
\cline { 2 - 6 } & всходы & колошение & уборка & уборка & уборка \\
\hline Контроль & 19,3 & 6,4 & 8,7 & 63,6 & 220,0 \\
\hline Аммиачная селитра & 19.3 & 10,0 & 12,2 & 60,4 & 217,0 \\
\hline Удобрение на основе коры сосны* & 19.3 & 9,2 & 10,0 & 68,0 & 255,0 \\
\hline
\end{tabular}

Примечание. * Удобрение содержит 20,0 мас. \% азота в виде аммиачной селитры.

На стадии колошения пшеницы отмечено существенное (в 3 раза) уменьшение содержания нитратного азота в контрольном опыте. Применение аммиачнй селитры и удобрения на основе коры сосны позволяет снизить вынос азота из почвы на данной стадии, поскольку его содержание в почве уменьшается не более чем в 2 раза. Повышенное содержание азота по сравнению с контролем сохраняется в опытах с удобрениями до уборки. Наиболее заметное различие в содержании азота при внесении в почву аммиачной селитры и удобрения на основе коры сосны отмечено на стадии уборки (табл. 5).

Содержание подвижного фосфора в почве на стадии уборки находится в пределах 60,4-68,0 мг/кг, а обменного калия - в пределах 217,0-255,0 мг/кг почвы. Сравнение с содержанием этих элементов в почве перед посевом (фосфора 50,4-67,4 мг/кг и калия 214,0269,7 мг/кг) показывает, что в течение вегетации пшеницы существенных изменений в содержании фосфора и калия не наблюдается. Внесение в почву удобрения на основе коры сосны обеспечивает более высокий уровень фосфора и калия в почве на момент уборки в сравнении с контрольным опытом и аммиачной селитрой (табл. 5). Можно предположить, что это является результатом перехода части фосфор- и калийсодержащих веществ сосновой коры в почву.

Повышенное содержание питательных элементов в почве в вегетационном периоде обеспечило повышение урожайности пшеницы в вариантах с удобрениями по сравнению с контрольным опытом на 2,7 ц/га при внесении в паровое поле перед посевом аммиачной селитры и на 2,9 ц/га при внесении азотсодержащего удобрения на основе коры сосны. Природа вносимых азотсодержащих удобрений мало влияет на урожайность пшеницы. Однако применение удобрения на основе коры сосны обеспечивает большую высоту растений, массу одного зерна и натуру зерна в сравнении не только с контролем, но и с аммиачной селитрой (табл. 6). Показатель «натура зерна» косвенно характеризует степень его налива и созревания, которые определяют пищевую ценность выращенной пшеницы. Значение натуры зерна, полученное в варианте полевого опыта с удобрением на основе коры сосны, максимально и подтверждает его большую эффективность по сравнению с аммиачной селитрой.

Зерно, выращенное в присутствии аммиачной селитры, содержит существенно больше азота и меньше фосфора по сравнению с другими образцами (табл. 7). Азот может присутствовать в зерне и в нитратной форме, что снижает экологическую безопасность полученной пшеницы. В этом отношении применение азотсодержащего удобрения на основе коры сосны 
Таблица 6. Характеристика посевов пшеницы сорта «Красноярская 12»

Table 6. Characteristic of sowing of wheat variety "Krasnoyarskay 12 "

\begin{tabular}{|c|c|c|c|c|}
\hline \multirow{2}{*}{\multicolumn{2}{|c|}{ Показатель }} & \multicolumn{3}{|c|}{ Вариант полевого опыта } \\
\hline & & \multirow{2}{*}{$\begin{array}{c}\begin{array}{c}\text { контроль } \\
\text { (без удобрений) }\end{array} \\
252\end{array}$} & \multirow{2}{*}{$\begin{array}{c}\text { аммиачная селитра } \\
252\end{array}$} & \multirow{2}{*}{$\begin{array}{c}\begin{array}{c}\text { удобрение на } \\
\text { основе коры } \\
\text { сосны* }\end{array} \\
254\end{array}$} \\
\hline Число растений, & всходы & & & \\
\hline шт./M² & уборка & 244 & 246 & 250 \\
\hline Высота растений, см & уборка & 108 & 109 & 115 \\
\hline \multirow{2}{*}{ Число стеблей, шт./м² } & общих & 267 & 269 & 269 \\
\hline & продуктивных & 265 & 265 & 267 \\
\hline Длина колоса, см & главный & $6-10$ & $6-9$ & $7-10$ \\
\hline \multirow{2}{*}{ Число в колосе, шт. } & колосков & $10-16$ & $12-16$ & $12-18$ \\
\hline & зерен & 35 & 36 & 37 \\
\hline \multirow{3}{*}{ Масса зерна, г } & одного зерна & 0,042 & 0,043 & 0,044 \\
\hline & с колоса & 1,4 & 1,5 & 1,5 \\
\hline & 1000 шт. & 41,8 & 42,8 & 43,7 \\
\hline Macca, $\Gamma$ & соломы & 2,9 & 3,0 & 2,9 \\
\hline $\begin{array}{l}\text { Урожайность, ц/га } \\
\operatorname{HCP}_{05}=2,7 \text { ц/га }\end{array}$ & зерна & 37,1 & 39,8 & 40,0 \\
\hline \multicolumn{2}{|l|}{ Натура зерна, г/л } & 768 & 772 & 778 \\
\hline
\end{tabular}

Примечание. * Удобрение содержит 20,0 мас. \% азота в виде аммиачной селитры.

Таблица 7. Содержание элементов питания в зерне пшеницы сорта «Красноярская 12»

Table 7. The nutrition elements content in seed of wheat variety "Krasnoyarskay 12"

\begin{tabular}{|l|c|c|c|}
\hline \multicolumn{1}{|c|}{ Вариант опыта } & Азот, \% & Фосфор, \% & Калий, \% \\
\hline Контроль & 1,12 & 2,32 & 1,33 \\
\hline Аммиачная селитра & 1,30 & 2,03 & 1,37 \\
\hline Удобрение на основе коры сосны* & 1,16 & 2,25 & 1,30 \\
\hline
\end{tabular}

Примечание. * Удобрение содержит 20,0 мас. \% азота в виде аммиачной селитры.

более эффективно, на что указывает более низкое содержание азота в зерне. Отмечено, что зерно, выращенное с применением данного удобрения и в контроле, по содержанию элементов питания отличается мало (табл. 7).

\section{Благодарности / Acknowledgements}

Работа выполнена в рамках проекта с КрасНИИСХ № 0287-2019-009 с использованием оборудования Красноярского регионального центра коллективного пользования ФИЦ КНЦ СО PAH.

The work was carried out within the framework of a project with Krasnoyarsk research institute of agriculture No. 0287-2019-009 using the equipment of the Krasnoyarsk Regional Center for Collective Use of the Federal Research Center of the KSC SB RAS. 


\section{Заключение}

Разработан способ получения азотсодержащего удобрения, основанный на пропитке подложки из коры сосны водным раствором аммиачной селитры. Удобрение имеет следующий состав (мас. \%): 42,83 подложка из коры сосны, 57,17 аммиачная селитра (20,0 азота). По результатам изучения свойств подложки из коры сосны показана эффективность удобрения на ее основе для улучшения структуры почвы, ее водного баланса и восполнения гумусовых веществ. Установленный характер распределения аммиачной селитры в матрице подложки определяет способность удобрения к замедленному вымыванию азота водой в течение длительного времени.

В результате проведения полевого опыта по выращиванию пшеницы сорта «Красноярская 12» выявлено ростостимулирующее действие азотсодержащего удобрения на основе коры сосны. Это удобрение по эффективности действия не уступает аммиачной селитре - урожайность пшеницы возросла на 2,9 и 2,7 ц/га соответственно. Внесение азотсодержащего удобрения на основе коры сосны приводит к увеличению натуры зерна в сравнении с аммиачной селитрой и неудобренным фоном, что характеризует более высокую пищевую ценность выращенного зерна.

Результаты полевого опыта показывают целесообразность продолжения полевых исследований удобрения на основе коры сосны для выявления эффекта его пролонгированного действия.

\section{Список литературы / References}

1. Информационно-технический справочник по наилучшим доступным технологиям ИТС 1-2015: Производство иеллюлозы, древесной массы, бумаги, картона. М: Бюро НДТ, 2015. 465 c. [A best available technologies reference document BREF 1-2015: Production of cellulose, wood pulp, paper, cardboard. M: The NDT Bureau, 2015. 465 p. (in Russ.)]

2. Best Available Techniques (BAT) Reference Document for the Production of Pulp, Paper and Board. Industrial Emissions Directive 2010/75/EU (Integrated Pollution Prevention and Control). Luxembourg: Publications Office of the European Union, 2015. 906 p.

3. Feng S., Cheng S., Yuan Z., Leitch M., Xu C. Valorization of bark for chemicals and materials: A review. Renewable and Sustainable Energy Reviews. 2013. Vol. 26, P. 560-578.

4. Беловежец Л.А., Волчатова И.В., Медведева С.А. Перспективные способы переработки вторичного лигноцеллюлозного сырья. Химия растительного сырья. 2010. № 2, С. 5-16. [Веlovezhets L.A., Volchatova I.V., Medvedeva S.A. Promising methods of processing secondary lignocellulose raw materials. Chemistry of plant raw materials. 2010. No. 2, P. 5-16. (In Russ.)]

5. Веприкова Е.В., Кузнецова С.А., Чесноков Н.В., Кузнецов Б.Н. Получение органоминеральных удобрений на основе древесной коры (Обзор). Журнал Сибирского федерального университета. Химия. 2016. Т. 9(4), C. 414-429. [Veprikova E.V., Kuznetsova S.A., Chesnokov N.V., Kuznetsov B.N. Obtaining organomineral fertilizers based on wood bark (Review). Journal of the Siberian Federal University. Chemistry. 2016. Vol. 9(4), P. 414-429. (In Russ.)]

6. Chang Tian, Xuan Zhou, Quang Liu, Jian-wei Peng, Wen-ming Wang, Zhan-hua Zhang, Yong Yang, hai-xing Song, Chan-yun Quan. Effects of a controlled-release fertilizer on yield, nutrient uptake and fertilizer usage efficience in early ripening rapeseed (Brassica napus L.). Journal of Zhejiang University - SCIENCE B (Biomedicine\&Biotechnology). 2016. Vol. 17(10), P. 775-786. 
7. Azeem B., Kushaari K.Z., Man Z.B. et al. Review on materials \& methods to produce controlled release coated urea fertilizer. Journal Control. Release. 2014. Vol. 181, P. 11-21.

8. Кудеяров В.Н. Баланс азота, фосфора и калия в земледелии России. Агрохимия. 2018. № 10, C. 3-11. [Kudeyarov V.N. Balance of nitrogen, phosphorus and potassium in agriculture in Russia. Agrochemistry. 2018. No. 10, P. 3-11. (In Russ.)]

9. Trenkel M.E. Slow- and Controlled - release and stabilized Fertilizers: An option for Ebhancing Nutrient Use Efficiency in Agriculture. Second edition. Paris: IFA, 2010. 160 p.

10. Ahmed S.A., Kim J.I., Park K.M., Chun S.K. Ammonium nitrate-impregnated woodchips: a slow-release fertilizer for plants. J. Wood Science. 2011. Vol. 57, P. 295-301.

11. Веприкова Е.В., Королькова И.В., Кузнецов Б.Н., Чесноков Н.В. Свойства азотсодержащего органоминерального удобрения на основе коры осины. Химия растительного сырья. 2018. № 4, C. 299-308. [Veprikova E.V., Korolkova I.V., Kuznetsov B.N., Chesnokov N.V. Properties of nitrogen-containing organomineral fertilizer based on aspen bark. Chemistry of plant raw materials. 2018. No. 4, P. 299-308. (In Russ.)]

12. Веприкова Е.В., Иванов И.П., Королькова И.В., Чесноков Н.В. Получение и свойства органо-минерального удобрения пролонгированного действия на основе коры пихты. Химия растительного сырья. 2020. № 2, С. 373-380. [Veprikova E.V., Ivanov I.P., Korolkova I.V., Chesnokov N.V. Obtaining and properties of organo-mineral fertilizers of prolonged action based on fir bark. Chemistry of plant raw materials. 2020. No. 2, P. 373-380. (In Russ.)]

13. Белаш М.Ю., Веприкова Е.В., Иванов И.П., Кузнецов Б.Н., Чесноков Н.В. Получение пористых материалов различного назначения из луба коры березы. Химия в интересах устойчивого развития. 2019. Т. 27(5), С. 453-459. [Belash M.Yu., Veprikova E.V., Ivanov I.P., Kuznetsov B.N., Chesnokov N.V. Obtaining porous materials from birch bark bast for various purposes. Chemistry for sustainable development. 2019. Vol. 27(5), P. 453-459. (In Russ.)]

14. Оболенская А.В., Ельницкая 3.П., Леонович А.А. Лабораторные работы по химии древесины и целлюлозы. М.: Экология, 1991. 320 c. [Obolenskaya A.V., Elnitskaya Z.P., Leonovich A.A. Laboratory work on the chemistry of wood and cellulose. M.: Ecology, 1991. 320 p. (In Russ.)]

15. Кураченко Н.Л., Колесникова В.Л., Колесников А.С., Романов В.Н. Агрофизическое состояние чернозема и продуктивность рапса, возделываемого по ресурсосберегающим технологиям в Красноярской лесостепи. Плодородие. 2015. № 3, C. 19-21. [Kurachenko N.L., Kolesnikova V.L., Kolesnikov A.S., Romanov V.N. Agrophysical state of chernozem and productivity of rapeseed cultivated using resource-saving technologies in the Krasnoyarsk forest-steppe. Fertility. 2015. No. 3, P. 19-21. (In Russ.)]

16. Романов В.Н., Заушинцена А.В., Кожевников Н.В. Применение показателей активности ферментов для оперативной диагностики экологического состояния агрогенных почв. Достижения науки и техники АПК. 2019. Т. 33(7), C. 44-47. [Romanov V.N., Zaushintsena A.V., Kozhevnikov N.V. Application of enzyme activity indices for operational diagnostics of the soils agrogenic state ecological. Achievements of Science and Technology of AIC. 2019. Vol. 33(7), P. 44-47. (In Russ.)]

17. Доспехов Б.А., Васильев И.П., Туликов А.М. Практикум по земледелию. М.: Агропроиздат, 1977. 301 с. [Dospekhov B.A., Vasiliev I.P., Tulikov A.M. Workshop on agriculture. M.: Agroproizdat, 1977. 301 p. (In Russ.)]

$$
-591-
$$


18. Доспехов Б.А. Методика полевого опыта. М.: Агропромиздат, 1985. 352 с. [Dospekhov B.A. Field experiment technique. M.: Agropromizdat, 1985. 352 p. (In Russ.)]

19. Методика Госкомиссии по сортоиспытанию с.-х. культур. М., 1963. [Methodology of the State Commission for variety testing of agricultural cultures. M., 1963 (In Russ.)]

20. Руководство по проведению регистрационных испытаний агрохимикатов в сельском хозяйстве. М., 2018. 217 c. [Guidelines for conducting registration tests of agrochemicals in agriculture. M., 2018. 217 p. (In Russ.)]

21. Методические рекомендации по оченке качества зерна. М.: ВАСХНИЛ,1978. 171 с. [Methodical recommendations for assessing the quality of grain. M.: AUAASNAL, 1978. 171 p. (In Russ.)]

22. Качинский Н.А. Физика почв. М.: Высшая школа, 1970. 360 с. [Kachinsky N.A. Soil physics. M.: Higher school, 1970. 360 p. (In Russ.)]

23. Александрова Л.Н., Найденова О.А. Лабораторно-практические занятия по почвоведению. Л.: Колос, 1967. 350 с. [Aleksandrova L.N., Naydenova O.A. Laboratory and practical classes in soil science. L.: Kolos, 1967. 350 p. (In Russ.)]

24. Руководство по анализам кормов. М.: Колос, 1982. 75 с. [Feed Analysis Guide. M.: Kolos, 1982. 75 p. (In Russ.)]

25. Снедекор Дж.У. Статистические методы в применении к исследованиям в сельском хозяйстве и биологии. М.: Изд-во с.-х. литературы, 1961. 503 с. [Snedecor J.W. Statistical methods in application to research in agriculture and biology. M.: Agricultural literature publishing house, 1961. 503 p. (In Russ.)]

26. Прогноз погоды в п. Минино, Емельяновский район Красноярского края - http://rumeteo.ru (май - сентябрь 2020 г). [Weather forecast for the Minino village, Yemelyanovskiy district of Krasnoyarsk Territory - http://ru-meteo.ru (May - September 2020). (In Russ.)]

27. Остроухова Л.А., Федорова Т.Е., Онучина Н.А., Левчук А.А., Бабкин В.А. Определение количественного содержания экстрактивных веществ из древесины, корней и коры деревьев хвойных видов Сибири: лиственницы (LARIX SIBIRICA L.), сосны (PINUS SYLVESTRIS L.), пихты (ABIES SIBIRICA L.), ели (PICEA OBOVATA L.) и кедра (PINUS SIBIRICA DU TOUR.). Химия растительного сырья. 2018. № 4, С. 185-195. [Ostroukhova L.A., Fedorova T.E., Onuchina N.A., Levchuk A.A., Babkin V.A. Determination of the quantitative content of extractive substances from wood, roots and bark of Siberian coniferous trees: larch (LARIX SIBIRICA L.), pine (PINUS SYLVESTRIS L.), fir (ABIES SIBIRICA L.), spruce (PICEA OBOVATA L.) and cedar ( PINUS SIBIRICA DU TOUR.). Chemistry of plant raw materials. 2018. No. 4, P. 185-195. (In Russ.)]

28. Промышленный катализ в лекциях. Вып. 1. Под ред. А.С. Носкова. М.: Калвис, 2005. 136 c. [Industrial catalysis in lectures. Issue 1. Ed. A.S. Noskov. M .: Kalvis, 2005. 136 p. (In Russ.)]

29. Позин М.Е. Технология минеральных солей (удобрений, пестицидов, промышленных солей, окислов и кислот). Ч. 2, 4-е изд. Л.: Химия, 1974. 768 с. [Pozin M.E. Technology of mineral salts (fertilizers, pesticides, industrial salts, oxides and acids). Part 2, ed. 4. L.: Chemistry, 1974. 768 p. (In Russ.)]

30. Sokrates G. Infrared and Raman characteristic group frequencies: Tables and charts. West Sussex: Wiley Sons, 2001. 347 p. 